\title{
The state as a space of health : On the geopolitics and biopolitics of health-care systems
}

\section{Kivelä, Satu}

2017

Kivelä , S \& Moisio , S M 2017 , ' The state as a space of health : On the geopolitics and biopolitics of health-care systems ' , Territory, Politics, Governance , vol. 5 , no. 1 , pp. 28-46 . https://doi.org/10.1080/21622671.2016.1158122

http://hdl.handle.net/10138/313052

https://doi.org/10.1080/21622671.2016.1158122

acceptedVersion

Downloaded from Helda, University of Helsinki institutional repository.

This is an electronic reprint of the original article.

This reprint may differ from the original in pagination and typographic detail.

Please cite the original version. 
In print in Territory, Politics, Governance (Routledge)

DOI: $10.1080 / 21622671.2016 .1158122$

Permanent link once published: http:// dx.doi.org/ 10.1080/21622671.2016.1158122

THE STATE AS A SPACE OF HEALTH: ON THE GEOPOLITICS AND BIOPOLITICS OF HEALTH-CARE SYSTEMS

\section{SATU KIVELÄ and SAMI MOISIO}

Author details: Satu Kivelä, RELATE Centre of Excellence, Department of Geography, University of Oulu, PO Box 3000, FI-90014 UNIVERSITY OF OULU, Finland. E-mail: satu.kivela@oulu.fi. Sami Moisio, RELATE Centre of Excellence, Department of Geosciences and Geography, University of Helsinki, PO Box 64, FI-00014 UNIVERSITY OF HELSINKI, Finland. Email: sami.moisio@ @elsinki.fi.

The historical transformations of state spaces have recently been theorized and conceptualized from multidisciplinary perspectives and in various spatial and temporal contexts, but less research has been concerned with the entanglement of biopolitics and geopolitics in transforming state spaces in the OECD world. This article seeks to develop an approach to the geopolitics/biopolitics interface by inquiring into the ways in which 'health' has been one of the key aspects of the territorial constitution of the so-called welfare state in the Finnish context, and how health care has been an important constituent of the recent re-working of state territory and citizen subjectivities. The paper suggests that the health care/state space nexus can be scrutinized through an analysis of historically contingent geopolitical and 
biopolitical rationalities and related governmental techniques, as well as through a contextsensitive inquiry into how the territorial system of health care has altered over time.

Keywords: state spatial transformation, biopolitics, geopolitics, health care, Finland

\section{INTRODUCTION}

In recent years, scholars interested in state theory have expressed a series of claims about the territorial constitution of states. These claims share the view that rather than as a static, discrete and self-enclosed territorial frame, state space should be conceptualized as a historically contingent and constantly transforming relational effect of socio-spatial processes, social practices and power relations within and beyond state boundaries (e.g. MITCHELL 1991; PAINTER 2010; also AGNEW 1994; TAYLOR 1994; BRENNER et al. 2003, pp. 126). Also, these claims collectively suggest that specific geopolitics (ROBERTS et al. 2003) and a distinctive political reasoning (MOISIO 2011) are increasingly being used to fuse a neoliberal mode of production to state space, resulting in re-scaling (BRENNER 2004) and transnationalization of state spaces (e.g. DEMIROVIĆ 2011).

By asking how the analysis of the spatial transformation of the state may be enriched, we for our part focus on the geopolitical and biopolitical aspects of state transformation. We suggest that the history of health care might well be written as a history of biopolitical and geopolitical problematizations and develop a perspective which centers on the ways in which geopolitics and biopolitics come together in the context of certain social practices related to health care. Our point of departure is the idea that population and territory are not separate realms but are inherently intertwined and governed in relation to each other (see also ELDEN 
2013). Following this view, we examine health care as one of the 'statist' social practices which bring together the geopolitical and the biopolitical.

As social entities, health care systems are neither static nor politically neutral. These systems not only are in a state of constant change (BARNETT and COPELAND 2010, p. 499) but also have, in conjunction with other social systems, a central role in reconstructing the state and social relations (SALTMAN and FIGUERAS 1997; also SALTMAN and BANKAUSKAITE 2006). Through a discussion of the Finnish case, we demonstrate how certain biopolitical and geopolitical rationalities have materialized as systems of health care at specific temporal conjunctures in a geographical context which is often associated with the Nordic model of statehood (see MOISIO et al. 2011).

The paper is in six sections. Section two focuses on the entanglement of geopolitics and biopolitics in the (re)constitution of state spaces, and suggests a methodological framework for the investigation of biopolitics and geopolitics of state transformation. Section three discusses the empirical research material of the paper. The fourth section turns to analyzing the changing geopolitics and biopolitics of health care in the Finnish context from the 1960s up until the early 1990s as fundamental elements of the constitution of what is often labeled the welfare state. Section five excavates the ways in which the geopolitical and the biopolitical have come together in the Finnish health care system since the 1990s. Finally, brief conclusions and proposals for future research follow in sixth section.

\section{GEOPOLITICS AND BIOPOLITICS OF STATE TRANSFORMATION}


Studies on state spatial transformation usually focus specifically on territorial restructuring processes and related social practices at particular temporal and spatial conjunctures (e.g. BRENNER 2004; BREATHNACH 2010; JONAS 2013; MOISIO and PAASI 2013). Most of these studies draw on the idea of a transition from a Keynesian-national welfare state regime to a Schumpeterian post-national competition state regime (JESSOP 2002, 2007) over the past thirty-plus years. These studies underline the seamless interconnections between territory and socio-spatial relations through which the modern state comes into being. Accordingly, the reconstitution of state spaces is actively produced through socio-economic struggles (see MACLEAVY and HARRISON 2010) as a response to perceived internal and external politico-economic pressures on the state, such as the quandary of 'globalization' (e.g. BRENNER 2004, p. 5).

Fairly little attention has been paid to the entanglement of geopolitical and biopolitical aspects of changing state spaces. This is regrettable given that the spatial formation of the state at a given historical conjuncture is arguably based on the entanglements of biopolitics and geopolitics as two forms of politics of calculation (see ELDEN 2013). In this paper we argue that the history of health care might well be written as a history of biopolitical and geopolitical problematizations in which different actors have sought to address 'the problem of how best to govern the population and territory of the state' (HINDESS 2005, p. 397; cf. BARRY et al. 1996, p. 7).

In our conceptualization, geopolitics refers to the territorialization of state power over a purportedly 'national' space (cf. COWEN and SMITH 2009) and to the related practices of security and inter-state competition. Biopolitics, in turn, we see as referring to the management and regularization of population as a collective in relation to its qualitative and 
quantitative biological features (e.g. birth rate, mortality and morbidity, etc.) 'which have their political and economic effects, and [...] become pertinent only at the mass level' (FOUCAULT 2003a, pp. 242-246). Biopolitics thus arises out of the 'discovery of population' (CURTIS 2002) in the context of the state, and in so doing, connects 'life' to the territorial organization of the state (cf. FOUCAULT 1980, pp. 139-140; RABINOW and ROSE 2006, pp. 196-197). Therefore, population, with its internal characteristics and regularities, is often conceived of as a geopolitical problem within wider state strategies. The state both regulates population's life processes and directs population's distribution within certain territory, resulting in particular spatialities of the state (FOUCAULT 2007, pp. 104108; also KEARNS 2014).

The coming together of biopolitics and geopolitics emerges in conjunction with the development of the nation state and its practices as well as with the statistical knowledge of the state and its populace (see ELDEN 2007; also CURTIS 2002; PAINTER 2013). What this entails is that biopolitics and geopolitics became mutually constitutive through the governmentalization of the state. Indeed, FOUCAULT (2007, p. 363) argues that the rise of biopolitical power does not signify a shift from the 'territorial state' to a 'population state' but rather a transition from a sovereign state defined by its territoriality to a 'state of government which essentially bears on the population and calls upon and employs economic knowledge as an instrument, [that] would correspond to a society controlled by apparatuses of security' (FOUCAULT 2007, p. 110). In other words, biopolitics does not render space or territory insignificant; rather, governmental techniques generated through the political problematizations of vital characteristics of population are to be applied to the entire state territory (FOUCAULT 1991, pp. 350-351). In fact, as ELDEN (2007, 2013) and others have 
pointed out, territory has increasingly become a political object of governmental interventions and calculation, specifically with respect to its qualities.

We suggest that understanding the ways in which population and territory come together through different 'statist' social practices is crucial in conceptualizing the historical constitution and transformation of the state (e.g. JONES 2008; MOISIO 2008). These social practices range from education to health and combine the control and management of population with territorial formations (MOISIO 2015).

State space, 'health care' and governmentality

The interconnections between the territorial state and health care are often taken for granted. A quick look at public health care nonetheless discloses the complex social processes that bind these issues together (see also MORAN 2000). First, as major materializations of welfare policies, health care systems of various kinds have had a critical role in the emergence of post-World War II welfare states. Secondly, public health care is seamlessly linked with the state-driven processes of reproducing labor (and with providing healthy people for the purposes of waging war as Marx suggested). Thirdly, since the 1980s, existing welfare state structures have been reconfigured through various health care reforms. In the OECD world, these reforms have arguably reflected the emerging presence of neoliberal rationalities in social practices (e.g. MCGREGOR 2001; PRINCE et al. 2006; TEGHTSOONIAN 2009). In consequence, publicly funded health care systems have gravitated towards competition- and market-based solutions (e.g. WENDT and KOHL 2010; PROPPER 2012; TUOHY 2012). Fourthly, health care plays a central role with regard to the relationship between state and citizenry. In other words, 'health' is one of the fields of social life through which state power 
is brought into the everyday life of citizens (see e.g. PAINTER 2006). Taken together, health care is in many ways a 'statist' social practice which blends the biopolitical and geopolitical aspects of the state.

Governmentality provides us with a fruitful perspective for analyzing the ways in which biopolitics and geopolitics are brought together in the practices of health care.

Governmentality, in its broadest sense, refers to techniques and practices designated to direct human behavior (FOUCAULT 1997, p. 81) or to the 'rationalization and systematization of a particular way of exercising political sovereignty through the government of people's conduct' (O'FARRELL 2005, p. 107). In other words, governmentality denotes the microand macro-political practices through which population is directed to act in a specific way and through which citizens are expected to govern themselves (FOUCAULT 2007, pp. 108-109). The analytics of governmentality thus focuses attention to the practices of governing people and spaces through the state (cf. VALVERDE 2007).

Health care represents one of the most significant practices through which the state attempts to govern population and individuals at a distance. It results from the discovery of population whereby authorities realize that the population has a reality of its own (birth, illness, etc.) that requires the intervention of government (ROSE et al. 2006, p. 87). Viewed not only as a medical but also as a broader societal problem, the health of the population emerges as a fundamental objective of political power and economic management, 'and it becomes necessary to organize around them an apparatus that will ensure not only their subjection but the constant increase of their utility' (FOUCAULT 2003b, p. 343; also PORTER 2011, pp. 18-19). 
In the following, we suggest a distinction between three overlapping but analytically distinguishable elements which can be used to empirically examine the health care/state space nexus. Firstly, the governmentality perspective on health care seeks to empirically identify the different geopolitical and biopolitical rationalities upon which the systems of health care are predicated. In such a view, certain historically contingent systems of health care accordingly emerge and are maintained and transformed through these geopolitical and biopolitical rationalities as well as the associated 'societal ills' the government seeks to cure (cf. DEAN 2010, p. 31; ROSE and MILLER 1992, p. 279). In other words, the history of health care might well be written as a history of biopolitical and geopolitical problematizations in which different actors have sought to address 'the problem of how best to govern the population and territory of the state' (HINDESS 2005, p. 397; cf. BARRY et al. 1996, p. 7).

Secondly, biopolitical and geopolitical rationalities are realized through governmental technologies (cf. MILLER and ROSE 2008). In the context of heath care, which is inextricably linked to the politics of knowledge and the practices of expertise (cf. PORTER 2011, pp. 18-19), this refers to the tools, devices, personnel, and systems of knowledge which enable various authorities to make visible and act upon the conduct of individuals and populations. These techniques of health care thus necessitate calculations and employ scientific knowledge of population health.

The third analytical element we suggest is the materializations of health care. Institutional materializations of health policies have been discussed for example by FOX (1986), who uses the term hierarchical regionalism to illustrate the particular logics of territorial organization of 
health systems in American and British contexts. Hierarchical regionalism refers to a rationalization according to which health policy should stimulate the creation of regional and institutional hierarchies of health and medical services with the understanding that they would distribute services more equitably and efficiently. In our view, the materializations of health care refer both to the institutional spaces as well as the human subjects which are produced by the practices of health care (DEAN 2010, pp. 43-44; WALTERS 2012, p. 18). Instead of direct forms of repression and constraint, the institutional spaces of health care - e.g. a centrally orchestrated system of hospitals and health centers - are constitutive of (mundane) state power (cf. ROSE 2001, p. 17). In this capacity, health care is closely linked to the reorganization of the socio-spatial relations of the state, and its changing configurations disclose the changing forms of governing the economic, social and personal life of citizens.

\section{RESEARCH MATERIALS}

We have collected an extensive set of research materials for an analysis of the geopolitics and biopolitics of the health care system in Finland from the 1960s up to the present. The research material consists of relevant policy documents covering the period 1965-2012, and therefore constitutes a period of nearly 50 years. The material consists of 26 national health care strategy documents (1972-1999), two target and action plans for social welfare and health care (2000-2007) and two national development programs for social welfare and health care (2008-2012). The most recent national development program for social welfare and health care addresses the years 2012-2015. The research material also includes two committee reports from 1965 and 1969, one strategy for health care for the years 1975-1979 and six government proposals to parliament from the period 1971-2010. These documents we view 
as relevant indicators of the biopolitical and geopolitical rationalization of collective health in Finland.

All the chosen documents have been formulated by state authorities or state agencies and thus can be regarded as reflecting a particular 'statist' political reasoning. The national strategies for health care have been compiled by the Finnish National Board of Health, which was obligated by the PRIMARY HEALTH CARE ACT (66/1972), implemented in 1972, to formulate and annually verify highly detailed five-year plans. These plans were annually confirmed by the government. The plans included detailed objectives and instructions for the development of the public health care system, definitions of the allocation of resources (e.g. funding, personnel and assignments of authorities) as well as statistics and follow-up data. Since the disbandment of the National Board of Health in 1993, national plans as well as target and action plans and development programs have been formulated by the Ministry of Social Affairs and Health and confirmed by the government. Strict state-centered steering and planning of health care has been gradually dismantled since the early 1990s, with the result that highly prescriptive plans have been replaced by recommendation-based programs. The current national development program for social welfare and health care defines the objectives and operations for reforming the health sector as well as related legislative projects, programs and recommendations. A variant of the genealogy approach is applied here in order to excavate the particular continuities and ruptures within which the rationalities, techniques and materializations of health care are consolidated into a distinguishable configuration.

\section{THE SYSTEMS OF HEALTH CARE AND THE SPATIAL CONSTITUTION OF} FINLAND 
The specific ways in which the health of the population is related to the spatial constitution of the state should be understood as a transition from one systemic configuration of statehood to another. This section interrogates the political rationalities, governmental techniques and materializations of the biopolitical and geopolitical configurations which characterize these transitions in the Finnish context. In order to demonstrate this argument, we will not periodize the general health policies of Finland (e.g. HARJULA 2007) or the general trajectory of the public health care system in this geographical context. Neither is our aim to demonstrate the construction of the Finnish welfare state in general or engage in comparative research of the variegated welfare policies of Europe or beyond. Rather, we discuss the Finnish case here only in order to illustrate the broader argument of the paper: systems of health care represent useful empirical research foci for analysis of the amalgamations of geopolitics and biopolitics which characterize the changing forms of statehood.

\section{Background: the invisible state apparatus}

The administrative responsibility for health care was channeled from the state to the municipalities already in 1869 (MATTILA 2006, p. 22), when 'Finland' was an autonomous part of the Russian Empire. Under Russian rule the state's contribution to public health care was not extensive, and the municipalities and various civic organizations interested in public health were the primary engines of health care measures. From the geopolitical perspective, the advocacy for so-called social medicine, and later public health, could be described as one of the hallmark nationalistic social movements of the era.

After independence in 1917, Finland was, in topographical terms, a spatially centralized entity characterized by the concentration of higher education, cultural institutions, as well as 
economic and political power in the southern part of the country, mainly in the capital city Helsinki. The state was marked by a stark core-periphery structure and a weak institutional system of territorial integration. This form of statehood was nonetheless also marked by early attempts to connect populations to the (home)land through land reforms (MOISIO 2012). In the 1920s, these reforms were coupled with nascent statistical practices which mapped resources and settlements of the state.

In the 1920s and 1930s, the Finnish state apparatus was largely invisible (barring the disciplinary power of the state symbolized by police) in the vast peripheries of the state: everyday welfare arrangements were primarily based on family responsibility and other local practices (MOISIO 2012). The territorial management of the state through institutionalized social security or planning systems that had already developed in other European contexts was largely absent. The 1920s and 1930s saw only sporadic attempts to forge a new arrangement between the state and localities through systems of health care. However, whereas in the late $19^{\text {th }}$ century social medicine appears to have been primarily a movement among doctors (see JAUHO 2007), the public health advocacy of the 1930s was a bourgeois social movement that was associated with broader geopolitical interests: the movement received important support from the Rockefeller foundation (cf. WREDE 2008; also YRJÄLÄ 2005).

The first coordinated attempts by the state to localize its power through a constitution of 'national health care' took place after the Second World War. Although the overall number of physicians was relatively low (VUORENKOSKI et al. 2008, p. 21), legislation on general medical care implemented in 1943 represented an early attempt to create an institutional foundation for a spatially cohesive municipal physician system. Similarly, in 1944 an 
extension to the law on municipal midwives (implemented already in 1921) obligated municipalities to contract midwives and public health nurses, fixing the right to maternal and child health care by law and institutionalizing a network of maternal and child health centers. As a result of advocacy by public health movements, maternal and child health centers also served as 'health houses' that provided inhabitants with outpatient services (see WREDE 2001).

Towards the welfare state: The fusion of geopolitics and biopolitics

The Second World War was a rupture that marked a sea change in the political rationalities upon which Finnish public policies were predicated. In short, the war demonstrated the fundamental necessity to locate the geopolitical issue of national unity at the core of the political agenda in a new spatial manner that would bring together citizen and state through the social and the territorial. Fostering the unity of the nation and rooting out political radicalism now became core political virtues in the political alliance which formed between the leading political parties.

The gradual re-working of Finland through this nascent yet fragile political consensus soon translated into geopolitical and biopolitical ideas on public health. In the 1950s, for instance, the priority gradually shifted toward the development of a hierarchical hospital system. In accordance with the hospital-building program introduced in association with the Hospital Law in 1956, a network of central and district hospitals was established by the late 1960s. This marked a fundamental shift in the ways in which state power was constituted territorially. Simultaneously, the responsibility for general hospitals was transferred from the central government to the municipalities. However, despite the early attempts to re-organize 
health services in the 1950s, the 'actually existing national health' did not see significant improvements, mainly due to major regional and socioeconomic inequities in availability of health services (VUORENKOSKI et al. 2008, pp. 21-22).

In the 1960s, connecting people and land - a marked feature of the 1920s and 1930s - ceased to be a priority in the state's strategies. A new, biopolitically articulated priority emerged with the aim of generating a new, growth-oriented citizen who was capable of participating in industrial processes, consumption, and state modernization, as well as connecting this citizen firmly to the institutional and symbolic structure of the state. It was in this context that individual health gradually came to be comprehended as a basic right of a particular geopolitical citizenry. Encouragement of "national growth and well-being through the promotion of social responsibility and the mutuality of social risk' (ROSE and MILLER 1992, p. 192) materialized in the social innovations related health care.

In the 1960s, for the first time in the history of Finland, the health of the population began to be considered a serious political problem that necessitated significant practices of governance. In order to develop a nationwide health care system, the Ministry of the Interior appointed a Public Health Committee in 1960 and a Public Health Commission in 1967 to investigate how best to govern the health of the entire 'nation'. The Committee and Commission were assigned to consider the options for regional and local reorganization of health care and to prepare a proposal for legislation on health care that compiled the fragmented collection of previously prescribed statutes into one consistent law (KANSANTERVEYSKOMITEAN MIETINTÖ 1965; KANSANTERVEYSTOIMIKUNNAN MIETINTÖ 1969). Management of health throughout the state territory was comprehended as a fundamental element in generating positive national development: it would bring into existence a loyal, productive, 
and fundamentally 'activated citizen' whose aggregated activities in the public and private sector would have a positive influence on both national economy and national security (KUUSI 1961, p. 57).

Since the 1960s in particular, the construction of the health care system in Finland was a central element in the concurrent constitution of the form of biopolitical and geopolitical statehood that is often dubbed the Nordic or Scandinavian welfare state (see ESPINGANDERSEN 1990). The construction of the entirely new public health care system was one of the key elements of the geopolitical consolidation of the Finnish state around the idea of nation as well as associated spatial Keynesianism. The development of the spatial system of health care, which culminated in the 1970s, was a state-orchestrated attempt to re-work the geopolitical management of the state and to re-construct the lives of the Finns in new 'statist' ways. The construction of the spatially extensive public health care system thus was not an extension of the existing biopolitical systems of an already existing 'welfare state' but should rather be understood (together with the emerging school system) as an institutional arrangement through which the welfare state as a biopolitical enterprise came into being. Moreover, health care was not simply one of the socio-spatial innovations that constituted the Finnish welfare state but should be conceived of as a unique biopolitical and geopolitical practice which brought together the state and the citizen subject in an entirely new way.

The territorial management of the state as well as the qualitative engineering of citizen subjects were fused in the extension of state-orchestrated health care. In sum, the construction of Finland as a welfare state was predicated on certain problematizations within the geopolitics/biopolitics interface: the potentially destabilizing social role of the post-war populous generation that had entered the job market in the early 1960s (i.e. the issue of 
political radicalism prompted by unemployment), the related social consequences of ill health and corresponding advantages of a healthy population, the integration of citizens into the national community, as well as the precarious geopolitical situation of Finland between two rapidly expanding economies - Sweden and the Soviet Union.

From the 1950s onwards the convergence of biopolitics and geopolitics (ELDEN 2013) was encapsulated in the issue of health care in Finland, and it could be argued that this coming together well characterizes the constitution of the welfare state in Finland more generally (MOISIO et al. 2011). The developments after the 1960s were considerable given that progress in health services since the 1940s had concentrated mainly on inpatient care and mother and child health while public health in general remained at a poor level in comparison to Western European countries (HE 98/1971, p. 1). In this context, the increased attention devoted to the 'economies of national health' was based on using scientific knowledge production to identify particular problems in the health/political order interface. First, there was a large working-age population in Finland compared to many other countries, but its health status was one of the poorest in Europe as indicated by statistics of mortality, morbidity and disability to work. Second, there were substantial regional and socioeconomic inequalities in access to health services, which were centralized in urban areas (the patient/doctor ratio was the lowest in Europe, tied with Albania). Third, the hospital-centered health policy was seen as a hindrance to economic efficiency due to rapidly increasing costs of inpatient care. Moreover, hospital-oriented care was perceived as an obstacle to the development of preventive primary health care and health promotion in general (HE 98/1971, p. 1). These problems can be interpreted as threats not only to economic growth and efficiency but also to territorial and societal equity and cohesion. In addition, economic and social inequalities between regions and socioeconomic groups were also understood as provoking societal 
disorder. The health care system that emerged from such articulations represented blunt statecentricity in terms of steering, coordinating, rationalizing and financing the system of national health (see e.g. VALTAKUNNALLISET SUUNNITELMAT... 1977-1981). In the early 1970s, health care was included in the national spatial planning system, which sought to reconfigure the spatialities of health care as a national issue. Indeed, in all the studied documents on health care (published in 1970s or 1980s), the state appears as both a real and symbolic guarantor of the welfare of individuals and the citizenry.

The early 1970s arguably represented a rupture within which geopolitical and biopolitical rationalities and associated techniques and materializations consolidated in a distinct spatial reconfiguration of Finland. Entirely new policies were introduced in 1972 when the Primary Health Care Act (66/1972) came into effect in order to effectively steer and improve the health of the population. The Act, based on a government proposal to parliament (HE 98/1971), aimed at the creation of an administrative and economic framework that would systematically and rapidly transform Finnish health care from a fragmented hospital-centered system into a workable and effective ensemble of outpatient and inpatient health care (HE 98/1971, pp. 1-3). The new legislation subsumed the health care sector into a centrally orchestrated national planning and steering system in order to harmonize the operational principles, methods and decision-making practices within health care (see e.g. VALTAKUNNALLINEN SUUNNITELMA... 1972-1976). This involved establishing 'social welfare and health care regions', extending these spaces throughout state space, as well as appointing the municipality as the primary unit of health care. A four-tier hierarchy of health care institutions ranging from a handful of university hospitals that were located in major cities and central hospitals located in provincial centers, to district hospitals in smaller towns, and finally to health centers in smaller municipalities, materialized in the 1970s (table 
1). This hierarchy was coupled with yet another constituent of state power: preventive health care became part of the re-worked school system in the 1970s, thus transforming schools into peculiar institutions of national health.

Table 1.

The new 'health spaces' of the state were implemented through a spatial/regional hierarchy of health services (cf. FOX 1986) which aimed not only to decrease health care costs, but also, in line with welfarist principles of equity and universalism, to increase regional and socioeconomic equality by securing accessible and publicly funded health services for all citizens (e.g. TERVEYDENHUOLLON OHJELMA VUOSILLE 1975-1979, p. 7; VALTAKUNNALLISET SUUNNITELMAT... 1975-1979, p. 5). Health services were regionalized at the local level by the establishment of an extensive network of municipal health centers in the 1970s. All primary health care services, ranging from general practice and dental care to health promotion and health education, were centralized to health centers, i.e. becoming the responsibility of municipalities (e.g. VALTAKUNNALLISET SUUNNITELMAT... 1978-1982, pp. 6-10). Consequently, the municipal health center became not only a vital symbol of the biopolitical and geopolitical formation of the Finnish 'national' welfare state but also a significant local site to reproduce labor.

The construction of a regional hierarchy of health care was more than a straight-forward establishment of municipal health centers. Specialized medical care and primary health care, which had operated as independent equations thus far, were brought together as an appropriate ensemble by collaboration and operation scaling: specialized care was supposed to answer only for such services that were not available in health centers. This form of 
hierarchy meant not only that health centers served as 'gatekeepers' between primary and specialized care but also that university hospitals in particular served as the pinnacle of the hierarchy, as hubs of knowledge on 'national health' (the so-called hospital districts were established by the Hospital Law already in 1956 during the onset of spatial Keynesianism) (e.g. VALTAKUNNALLISET SUUNNITELMAT... 1980-1984, pp. 16-22). The university hospitals were also associated with scientific biopolitical knowledge-production on 'national health', its spatial variations and characteristics. These studies on public health status were accompanied by statistics and mapping which translated public health into a calculable and governable biopolitical problem that could be acted upon.

The network of health centers was generated and maintained through centrally orchestrated techniques of governance such as transfer payments to municipalities. In spite of their selfgovernment, municipalities were nonetheless subjugated to centralized steering (e.g. VALTAKUNNALLINEN SUUNNITELMA... 1972-1976). The state set the objectives of primary and specialized care, defined the methods for achieving the objectives, and determined resources (e.g. financing and personnel) and their allocation - only the implementation of the plans was the responsibility of the municipalities (e.g. VALTAKUNNALLISET SUUNNITELMAT... 1975-1979, pp. 1-22). In order to decrease regional inequalities, the Ministry of Finance regulated the grant system through a financial classification of municipalities thereby ensuring equal premises for municipalities to provide statutory health services to their inhabitants also in the eastern and northern peripheries and outside the largest urban centers (e.g. VALTAKUNNALLISET SUUNNITELMAT... 1975-1979, p. 29). Municipalities thus remained not only fundamental institutional and spatial foundations for health care but also key spaces in citizens' everyday lives. By ensuring universal and mainly free municipal health services and by providing extensive social rights 
to all citizens regardless of their socioeconomic status or place of residence, municipalities acted as local states through which social citizen subjectivities were constructed and brought into being as a facet of state power. This spatial division of labor indicated not only that the state was dependent on the institutional foundation that municipalities represented with respect to health care but also that the municipalities became highly dependent on state subsidies. From the 1970s onwards, the Finnish health care system began to symbolize the principles of social and spatial universalism which characterize the so-called Nordic model of statehood (AHLQVIST and MOISIO 2014). In the ensuing pages, we proceed to analyze whether the merger of geopolitics and biopolitics which characterized the construction of Finland as a 'welfare state' has changed since the 1990s.

\section{TOWARDS A NEW BIOPOLITICAL AND GEOPOLITICAL FORMATION IN} FINLAND?

The crisis of the welfare state: emergence of new political rationalities

From the 1960s to the 1980s spatial Keynesianism (and associated welfarism) brought together the biopolitical and geopolitical practices of health care in Finland. However, increasing emphasis on economic growth and competitiveness in the global 'knowledge economy' as well as growing criticism towards 'a planning state' resulted in various policy reforms in the 1990s, particularly (MOISIO 2012, p. 165) when, in line with advanced liberalism (see ROSE 1993) and the New Public Management doctrine, major political, economic and societal changes were implemented in response to an economic recession which took place between 1991 and 1994. Criticism of the hierarchical and centrally planned Finnish state, which culminated during the recession of the 1990s, sundered the traditional 
political alliance between the Social Democrats and the Center Party upon which the Finnish brand of spatial Keynesianism had rested. The blame for the malfunctions of the centrally planned economy and society was assigned to the 'bloated' state per se, and a notable elite consensus was structured around the idea. The economic crisis of the early 1990s was thus a rupture from which new political rationalities emerged and merged with other rationalities (cf. HEISKALA 2006, pp. 14-15). The crisis itself took place within the context of a wider geopolitical rupture: the collapse of the Soviet Union and the territorial expansion of the EC/EU.

In order to prod local governments to make more independent and more cost-effective decisions (HE 101/1981, p. 6; VALTAKUNNALLISET SUUNNITELMAT... 1984-1988, p. 58), state-centered planning and steering of health care was reduced already in the $1980 \mathrm{~s}$. Given this trend, it is notable that the territorial basis of the health care system has largely endured up until the present. Nevertheless, it is equally important to point out that the territorial structures of health care have become a useful testing ground for neoliberal experimentation. In the present analysis, it is precisely the broadly 'economic-strategic' nature of spatial Keynesianism in Finland - which brought together territorial integrity, economic growth and the idea of a politically loyal 'useful' citizenry - which has provided the legitimation for a range of health care reforms that are predicated on advanced liberalism. Since the 'small recession' of 2002, these reforms have substantially intensified.

The geoeconomics of advanced liberalism and individualization of national health

The gradual shift from spatial Keynesianism and associated welfarism towards advanced liberalism has materialized in Finland through a variety of health policy projects launched 
since the early 1990s. What unites these projects is an increasingly explicitly articulated attempt to introduce market and quasi-market arrangements in health care. These have been coupled with an emphasis on empowerment, self-government and responsibility in the context of 'national health' (more generally, see HINDESS 2005, p. 409). Since the so-called little recession of 2002 in particular, health policy reforms in Finland have been directed towards producing 'updated' state spaces and new citizen subjectivities (cf. MOISIO and PAASI 2013, pp. 275-277). Since then, it has become clear that the geopolitical function of the health care system, i.e. producing territorial homogeneity, has been overshadowed by an imperative of the 'economic survival' of the nation. This imperative resonates with many of the principles of austerity politics (see BLYTH 2013), and is premised on cost-minimization and efficiency of the public sector as well on the individualization of health.

As part of the emergence of governmental interventions seeking to update the spatial structures of the state through economistic political reasoning, in 1993 centralized planning and steering in health care was dismantled in Finland (see HE 216/1991; VALTAKUNNALLINEN SUUNNITELMA... 1993-1996, pp. 1-2). This was the first step not only in altering the existing power relations between the state and its municipalities but also in reconfiguring the state's biopolitical right to regulate population health (cf. FOUCAULT 2003a, p. 241). The problematics of central planning and steering in health care and other public services was attributed particularly to the economic ineffectiveness of the Finnish state as a territorial entity. A public sector that was conceived of as 'outdated and uneconomical' (HE 216/1991, p. 4) was to be modernized through new geopolitical and biopolitical discourses and practices of governance which on the one hand would decrease state interventions in the health care sector, and on the hand would reduce both local governments' and citizens' dependency on the state. 
Since the 1990s, the Finnish local governments have been increasingly directed through techniques based on non-binding information management and recommendations (SOSIAALI- JA TERVEYDENHUOLLON... 2004-2007, pp. 32-33). The rationalization behind this deregulation was that centralized steering restricted municipalities' autonomy to organize and produce health services in a way that took local conditions into account (HE 214/1991; HE 216/1991). This is in stark contrast to the welfarist geopolitical reasoning of the 1970s and 1980s which sought, in the name of 'equal citizenship rights' and spatial justice, to harmonize operational principles, methods and decision-making practices of the entire health care system. Deregulation was now legitimized using the argument that because the universal nationwide health care system had been fully implemented in the previous era, strict state intervention was increasingly unnecessary (HE 216/1991).

Consequently, municipalities were given autonomy to decide on the production and organization of municipal health services and thus local governments were given freedom to purchase health services from private and third sectors without restrictions (VALTAKUNNALLINEN SUUNNITELMA... 1993-1996, p. 2). This governance through 'freedom' can be comprehended as a technique through which market mechanisms and quasimarkets have been encouraged and inculcated in the health care sector. As a result, the share of health services provided by the private sector has increased considerably over the course of the last decade (OLLILA and KOIVUSALO 2009, p. 29). At present, both the private and the third sector are portrayed as necessary actors in the production of adequate municipal health services (HE 155/2006, p. 68). 
Since 1993, in tandem with the onset of deregulation, the local government grant system has underwent reforms in order to 'responsibilitize' local governments to make decisions which meet particular standards of productivity (e.g. HE 216/1991). In 1993, the basis of grant payments was redesigned so that retrospective and earmarked payments were replaced by prospective subsidies based on capitated needs (VALTAKUNNALLINEN SUUNNITELMA... 1993-1996, p. 1) which resulted in considerable reduction of state subsidies for municipalities and thus marked a shift in fiscal responsibility from state to municipalities in terms of health care financing (VUORENKOSKI et al. 2008, p. 25, 44). Further, the financial classification of municipalities was discontinued in 1996 (KUNNALLISEN... ... 1996-1999, p. 18), which introduced an alternative governmental technique to spatial equalization compared to the preceding highly distributional policy. In line with the increasingly vocal criticism of the dispersed spatiality of the state, the present grant system directs and incentivizes voluntary municipality mergers amongst local governments and encourages more intensive cooperation between municipalities and regions (SOSIAALI- JA TERVEYDENHUOLLON... 2004-2007, p. 10, 36). In tandem with the decreasing number of municipalities (317 in 2015), the number of municipal health centers has decreased from 280 in 2004 to 152 in 2013 (RINTANEN et al. 2014, p. 8). It is noteworthy, however, that irrespective of the fact that the Finnish government has launched a number of spatial experiments that have sought to re-work the prevailing dispersed geopolitical constellation of the health care system over the past decade, the territorially comprehensive health care system has proven to be a rather entrenched structure of the state.

The centrally orchestrated grant system appears as a crucial governmental technique of spatial regulation that is utilized by social and advanced liberal government alike. The essential difference between social government and advanced liberalism nonetheless pertains to the 
ways in which state space is regulated through the grant system. In social government, the underlying purpose of the grant system was spatial equalization as well as the non-polarized distribution of population within state territory achieved via distributional policies, i.e. resources were allocated according to the financial capacity of the municipalities. This principle played a pivotal role in maintaining the dispersed spatiality of the welfare state. In advanced liberal government, in turn, the main objective of the grant system is to encourage municipalities to 'behave' in certain ways that increase the 'productivity' of the public sector and increase competition between the public and private health care. With 'framework budgeting', this has been the only way to compel the municipalities to the principles of the austerity regime.

In Finland, the diminishing role of the discourse of territorial integrity in contemporary state projects, and the related emphasis on internationalization, productivity and economic competitiveness, is the new geopolitical setting in which the biopolitical discourses of nation are presently situated. Even if the territorially extensive health care system has not been entirely deteriorated, it has been qualitatively re-worked. This re-working has explicitly touched upon the issue of citizen subjectivities (cf. ROSE 1999). In contemporary health care policies, it has become increasingly common to articulate a difference between the purportedly old 'state-dependent citizen' and a more activated citizen who is capable of understanding the individual responsibility of enhancing and maintaining good health, and who is therefore committed to managing health risks (e.g. SOSIAALI- JA TERVEYDENHUOLLON... 2012-2015, p. 9). The conduct and qualities as well as the economic potential of this rationally calculating citizen are shaped by techniques of activation and responsibilization like fostering participation, self-governance and individual choice. Along with this emphasis on customer orientations as a means to reconstruct and develop the 
health care system, the citizen has become increasingly viewed as a customer and consumer of health services (e.g. SOSIAALI- JA TERVEYDENHUOLLON... 2008-2011; HE 90/2010). Although vouchsafing the well-being and health of the entire 'national population' has remained a pivotal target of government, the population is now governed in not quite the same ways as during the construction of the welfare state. That is, with the individualization of national health, biopolitics of health care is increasingly structured around entrepreneurial citizen subjectivity and 'individual health' (cf. ROSE 2001, pp. 17-20; also GORDON 1991, p. 44). In other words, the interest has turned from guiding and controlling the political mass behavior of 'industrial' citizen subjects towards monitoring and managing the behavior of the contemporary 'post-industrial citizen subjects' with respect to their interior lives. The message of the recent reforms of health care is not so much that the health of individuals is simply their own responsibility, but rather that the production of increasingly resilient individuals through the health care system is an integral part of the competitiveness strategies of the state itself. In the recent structural adjustments of health care, citizens are indeed portrayed as calculating entrepreneurs of a novel 'productive state'.

With regard to the above, a notable aspect of the biopolitics of the contemporary health care system in Finland is the pivotal role of economic authorities, who work both within and beyond the state apparatus, in guiding the transformation of the health care system and suggesting experiments that would influence the interior lives of citizens. Since the 1990s, and during the past ten years in particular, the Ministry of Finance has played a central role in directing the health care system toward new geopolitical and biopolitical dimensions. Most of the core documents upon which the reforms of the health care system are predicated rely heavily on the calculations of the Ministry of Finance. It is indeed peculiar how the Ministry of Finance, through different kinds of domestic calculations and international comparisons, 
has made the system of health care amenable to economic measurement and calculus, and in so doing made the system an integral part of 'national systems of productivity' and an element of the international competitiveness of the state. During the past fifteen years, the calculations, proposals and incentives of the Ministry disclose a shift in the ways in which the state seeks to govern the souls of individuals in the context of health care, and the ways in which the Ministry seeks to restructure the extensive territorial basis of this system.

\section{CONCLUDING REMARKS}

In this article, we have examined the ways in which state spatial transformation can be examined through the changing systems of health care. We have suggested that an inquiry into these systems could make use of the concepts of geopolitics and biopolitics. We have highlighted that an analysis of this kind should focus on the political rationalities and associated problematics related to 'national health', and should examine the governmental techniques of health care which enable different authorities to modify the conduct of individuals and population. We have also suggested that both the subjectivities produced by health-related governmental practices and the territorial spaces of health care should be interrogated as materializations of the state as a space of health.

According to our genealogical analysis, particular biopolitical and geopolitical rationalities came together during the construction of the statist health care system. We view this coming together as one of the central aspects of the constitution of Finland as a welfare state. In the course of $20^{\text {th }}$ century, the focus of health policy in Finland evolved from the issues of hygiene that dominated in the first half of the century to broader questions of public and welfare policies in the post-war period (see HARJULA 2007). In the 1960s, when the 
emphasis shifted from maternal and child care and high-cost inpatient care to the health of the entire population and lower-cost preventive, primary and outpatient care, health was given higher priority in line with the socio-political objectives of the era: societal order, economic growth and national development (HE 98/1971; also KUUSI 1961). State-orchestrated development of a spatially organized hierarchical system of health services was understood not only as a means to enhance economic efficiency and regional and socioeconomic cohesion but also as a way to manage citizens' health-related conduct by providing them with broad social rights (e.g. HE 98/1971). Therefore, health policy can be conceived of as an ‘intermediary’ policy which on the one hand intensified the relationship between state and citizen, and on the other enabled the 'statist' practices upon which the constitution of the state was predicated. The recent health care reforms in Finland demonstrate, in turn, that the state has not ceded its role as a director of the territorial and biopolitical aspects of the health of its population. In other words, the Finnish state has not been hollowed out as a space of health, even if there has been a qualitative shift in the ways in which political power is practiced through 'national health'.

Taken together, the inquiry into Finland suggests that health care has been and is still a vital element in those reconfiguration processes that seek to transform previously constructed state spatialities and citizen subjectivities and consolidate them into new forms. These are increasingly conceived of as formations that need conform to global politico-economic realities. The relative absence of the discourse of competitiveness in no wise indicates that the re-working of health care in Finland is detached from 'internationalized' state spaces. While it may well be a gross exaggeration to argue that spatial Keynesianism (and the associated geopolitical calculus) has been completely replaced by advanced liberalism in Finland, our paper highlights a particular duality which is built into the contemporary system of health care 
with respect to political rationalities, governmental techniques and institutional materializations. The territorial structures of health care have proven to be reasonably durable in the face of neoliberal rationalities (see e.g. PECK 2013), and the principles of universalism and spatial and socio-economic equality are still central (discursive) elements in the policies that bring together state space and the issue of health. In the Finnish context, the inherited geopolitical spaces of the welfare state thus both hinder but also enable the neoliberalization of the state by facilitating health care-related socio-spatial practices that combine welfare rhetoric with incrementally implemented reforms aimed at dismantling the inherited territorial structures of the state (see AHLQVIST and MOISIO 2014).

We have sought to demonstrate that an examination of the relation between geopolitics and biopolitics in the context of health care offers insights into the study of the spatial transformation of the state and the diverse processes of neoliberalization. While the territorial structures of health care may remain relatively intact, the ways in which biopolitics works through these inherited geopolitical structures is a topic which merits more attention in different contexts.

As indicated in this paper, state spatial transformation also includes reconstruction of citizen subjectivities. With regard to subjectification and citizenship in general, it is of high importance to inquire further into the mundane political and social practices of health care through which state power permeates into the everyday life of citizens (see PAINTER 2006). Furthermore, as health care is nowadays increasingly entangled, for instance, with the issues of Europeanization (e.g. MARTINSEN and VRANGBÆK 2008) and global health (e.g. BROWN et al. 2012), another important research theme is the emergent transnationalization 
of health policies and practices as well as the associated potentiality of increasing marketization of health care services.

\section{ACKNOWLEDGEMENTS}

Academy of Finland is acknowledged for research funding (RELATE CoE, grant 272168).

\section{REFERENCES}

AGNEW J. (1994) The territorial trap: the geographical assumptions of international relations theory. Review of International Political Economy 1(1) 53-80.

AHLQVIST T. and MOISIO S. (2014) Neoliberalization in a Nordic state: from cartel polity towards a corporate polity in Finland. New Political Economy 19(1) 21-55.

BARNETT R. and COPELAND A. (2010) Providing health care. In BROWN T., MCLAFFERTY S. and MOON G. (Eds) A Companion to Health and Medical Geography, pp. 497-520. Wiley-Blackwell, Malden, MA.

BARRY A., OSBORNE T. and ROSE N. (1996) Introduction. In BARRY A., OSBORNE T. and ROSE N. (Eds) Foucault and Political Reason: Liberalism, Neo-liberalism and the Rationalities of Government, pp. 1-18. Routledge, Abingdon, Oxon.

BLYTH M. (2013) Austerity: the history of a dangerous idea. Oxford University Press, Oxford. 
BREATHNACH P. (2010) From spatial Keynesianism to post-Fordist neoliberalism: emerging contradictions in the spatiality of the Irish state. Antipode 42(5) 1180-1199.

BRENNER N. (2004) New State Spaces. Urban Governance and the Rescaling of Statehood. Oxford University Press, Oxford.

BRENNER N., JESSOP B., JONES M. and MCLEOD G. (2003) Introduction: state space in question. In BRENNER N., JESSOP B., JONES M. and MCLEOD G. (Eds) State Space: A Reader, pp. 1-26. Blackwell, Malden, MA.

BROWN T., CRADDOCK S. and INGRAM A. (2012) Critical interventions in global health: governmentality, risk, and assemblage. Annals of the Association of American Geographers $102(5)$ 1182-1189.

COWEN D. and SMITH N. (2009) After geopolitics? From the geopolitical social to geoeconomics. Antipode 41(1) 22-48.

CURTIS B. (2002) Foucault on governmentality and population: the impossible discovery. Canadian Journal of Sociology 27(4) 505-533.

DEAN M. (2010) Governmentality. Power and Rule in Modern Society. $2^{\text {nd }}$ ed. Sage Publications, Thousand Oaks, CA.

DEMIROVIĆ A. (2011) Materialist state theory and the transnationalization of the capitalist state. Antipode 43(1) 38-59. 
ELDEN S. (2007) Governmentality, calculation, territory. Environment and Planning D: Society and Space 25(3) 562-580.

ELDEN S. (2013) How should we do the history of territory? Territory, Politics, Governance 1(1) 5-20.

ESPING-ANDERSEN G. (1990) The three worlds of welfare capitalism. Polity Press, Cambridge, UK.

FOUCAULT M. (1980) The History of Sexuality. Volume 1: The Introduction. The Harvester Press, Brighton.

FOUCAULT M. (1991) Space, knowledge and power. In FAUBION J. D. (Ed.) Power. Essential works of Foucault, 1954-1984, pp. 349-364. The New Press, New York, NY.

FOUCAULT M. (1997) On the government of the living. In RABINOW P. (Ed.) Ethics: Subjectivity and Truth. Essential Works of Michel Foucault 1954-1984, pp. 81-85. The New Press, New York, NY.

FOUCAULT M. (2003a) Society Must Be Defended. Lectures at the Collège de France 19751976. Picador, New York, NY. 
FOUCAULT M. (2003b) The politics of health in the eighteenth century. In RABINOW P. and ROSE N. (Eds) The Essential Foucault. Selection from Essential Works of Foucault, 1954-1984, pp. 338-350. The New Press, New York, NY.

FOUCAUlT M. (2007) Security, Territory, Population. Lectures at the Collège de France 1977-1978. Palgrave Macmillan, New York, NY.

FOX D. M. (1986) Health policies, health politics. Princeton University Press, Princeton, NJ.

GORDON C. (1991) Governmental rationality: an introduction. In BURCHELL G., GORDON C. and MILLER P. (Eds) The Foucault Effect: Studies in Governmentality, pp. 151. The University of Chicago Press, Chicago, IL.

HARJULA M. (2007) Terveyden jäljillä. Suomalainen terveyspolitiikka 1900-luvulla. Tampere University Press, Tampere.

HE 98/1971 (1971) Hallituksen esitys Eduskunnalle kansanterveystyöstä ja sen voimaanpanosta annettaviksi laeiksi. (available at: http://www.edilex.fi/he/arkisto/kaikki/1971 ?perpage=50\&offset=101) (accessed on 31 January 2015).

HE 101/1981 (1981) Hallituksen esitys Eduskunnalle sosiaali- ja terveydenhuollon suunnittelua ja valtionosuutta koskevan lainsäädännön uudistamisesta. Valtiopäivät 1981: A 2. Valtion painatuskeskus, Helsinki. 
HE 214/1991 (1991) Hallituksen esitys Eduskunnalle kuntien valtionosuuslaiksi ja siihen liittyväksi lainsäädännöksi. (available at: http://www.edilex.fi/he/19910214) (accessed on 31 January 2015).

HE 216/1991 (1991) Hallituksen esitys Eduskunnalle sosiaali- ja terveydenhuollon suunnittelua ja valtionosuutta koskevan lainsäädännön uudistamisesta. (available at: http://www.edilex.fi/he/19910216) (accessed on 31 January 2015).

HE 155/2006 (2006) Hallituksen esitys Eduskunnalle laiksi kunta- ja palvelurakenneuudistuksesta sekä laeiksi kuntajakolain muuttamisesta ja varainsiirtoverolain muuttamisesta. (available at: http://www.finlex.fi/fi/esitykset/he/2006/20060155) (accessed on 31 January 2015).

HE 90/2010 (2010) Hallituksen esitys Eduskunnalle terveydenhuoltolaiksi sekä laeiksi kansanterveyslain ja erikoissairaanhoitolain muuttamiseksi sekä sosiaali- ja terveydenhuollon asiakasmaksuista annetun lain muuttamiseksi. (available at: http://www.finlex.fi/fi/esitykset/he/2010/20100090) (accessed on 31 January 2015).

HEISKALA R. (2006) Kansainvälisen toimintaympäristön muutokset ja Suomen yhteiskunnallinen murros. In HEISKALA R. and LUHTAKALLIO E. (Eds) Uusi jako: miten Suomesta tuli kilpailukyky-yhteiskunta?, pp. 14-42. Gaudeamus, Helsinki.

HINDESS B. (2005) Politics as government: Michel Foucault's analysis of political reason. Alternatives 30(4) 389-413. 
JAUHO M. (2007) Kansanterveysongelman synty. Tuberkuloosi ja terveyden hallinta

Suomessa ennen toista maailmansotaa. Tutkijaliitto, Helsinki

JESSOP B. (2002) The Future of the Capitalist State. Polity, Malden, MA.

JESSOP B. (2007). State Power: A Strategic-Relational Approach. Polity Press, Cambridge.

JONAS A. E. G. (2013) City-Regionalism as a contingent 'geopolitics of capitalism'.

Geopolitics 18(2) 284-298.

JONES M. (2008) Recovering a sense of political economy. Political Geography 27(4) 377399.

KANSANTERVEYSKOMITEAN MIETINTÖ (1965) Komiteanmietintö 1965: B 72.

Helsinki.

KANSANTERVEYSTOIMIKUNNAN MIETINTÖ (1969) Komiteanmietintö 1969: A 3.

Helsinki.

KEARNS, G. (2104) Governing vitalities and the security state. Environment and Planning D: Society and Space 32(5) 762-778.

KUNNALLISEN SOSIAALI- JA TERVEYDENHUOLLON TAVOITTEET JA

TOIMINTAPERIAATTEET: VALTAKUNNALLINEN SUUNNITELMA SOSIAALI- JA 
TERVEYDENHUOLLON JÄRJESTÄMISESTÄ VUOSINA 1996-1999 (1995). Ministry of Social Affairs and Health, Helsinki.

KUUSI P. (1961) 60-luvun sosiaalipolitiikka. WSOY, Porvoo.

MACLEAVY J. and HARRISON J. (2010) New state spatialities: perspectives on state, space, and scalar geographies. Antipode 42(5) 1037-1046.

MARTINSEN D. S. and VRANGBÆK K. (2008) The Europeanization of health care governance: implementing the market imperatives of Europe. Public Administration 86(1) $169-184$.

MATTILA Y. (2006) Suomen terveydenhuollon ja sairausvakuutuksen kehityslinjat: 'yhteisestä pohjasta eri poluille'. Turun yliopiston Sosiaalipolitiikan laitoksen julkaisuja Sarja D:2/2006 Sosiaalivakuutuksen ammatilliset lisensiaattitutkielmat.

MCGREGOR S. (2001) Neoliberalism and health care. International Journal of Consumer Studies 25(2) 82-89.

MILLER P. and ROSE N. (2008) Governing the Present: Administering Economic, Social and Personal Life. Polity Press, Cambridge.

MITCHELL T. (1991) The limits of the state: beyond statist approached and their critics. American Political Science Review 85(1) 77-96. 
MOISIO S. (2008) Towards attractive and cost-efficient state space: political geography of the production of state transformation in Finland. World Political Science Review 4(3) 1-34.

MOISIO S. (2011) Beyond the domestic-international divide: state spatial transformation as neo-liberal geopolitics. In AALTO P., HARLE V. and MOISIO S. (Eds) International Studies: Interdisciplinary Approaches, pp. 149-177. Palgrave Macmillan, Basingstoke.

MOISIO S. (2012) Valtio, alue, politiikka. Suomen tilasuhteiden sääntely toisesta maailmansodasta nykypäivään. Vastapaino, Tampere.

MOISIO S. (2015) Geopolitics/critical geopolitics. In AGNEW J., MAMADOUH V., SECOR A. and SHARP J. (Eds) The Wiley Blackwell Companion to Political Geography, pp. 220-234. Wiley Blackwell, Oxford.

MOISIO S., STOKKE K., SÆTHER E., LARSEN H. G., EK R. and LUND HANSEN A. (2011) Interventions in Nordic political geographies. Political Geography 30(5) 241-249.

MOISIO S. and PAASI A. (2013) From geopolitical to geoeconomic? The changing political rationalities of state space. Geopolitics $\mathbf{1 8 ( 2 )} 267-283$.

MORAN M. (2000) Understanding the welfare state: the case of health care. British Journal of Politics and International Relations 2(2) 135-160.

O’FARREL C. (2005) Michel Foucault. Sage Publications, London. 
OLLILA E. and KOIVUSALO M. (2009) Hyvinvointipalvelusta liiketoiminnaksi terveydenhuollon parantamisen tärkeät valinnat. In KOIVUSALO M., OLLILA E. and ALANKO A. (Eds) Kansalaisesta kuluttajaksi. Markkinat ja muutos terveydenhuollossa, pp. 21-47. Gaudeamus, Helsinki,

PAINTER J. (2006) Prosaic geographies of stateness. Political Geography 25(7) 752-774.

PAINTER J. (2010) Rethinking territory. Antipode 42(5) 1090-1118.

PAINTER J. (2013) Regional biopolitics. Regional Studies 47(8) 1235-1248.

PECK J. (2013) Explaining (with) neoliberalism. Territory, Politics, Governance 1(2) 132157.

PRIMARY HEALTH CARE ACT 66/1972 (1972). Ministry of Social Affairs and Health of Finland. (available at: http://www.finlex.fi/en/laki/kaannokset/1972/19720066) (accessed on 31 January 2015).

PRINCE R., KEARNS R. and CRAIG D. (2006) Governmentality, discourse and space in the New Zealand health care system, 1991-2003. Health \& Place 12(3) 253-266.

PROPPER C. (2012) Competition, incentives and the English NHS. Health Economics 21(1) $33-40$. 
PORTER D. (2011) Health Citizenship. Essays in Social Medicine and Biomedical Politics.

UC Medical Humanities Consortium, San Francisco, CA.

RABINOW P. and ROSE N. (2006) Biopower today. BioSocieties 1(2) 195-217.

RINTANEN H., PUROMÄKI H. and HEINÄMÄKI L. (2014) Terveyskeskusten avosairaanhoidon järjestelyt Suomessa. Työpaperi 18/2014. National Institute for Health and Welfare, Helsinki.

ROBERTS S., SECOR A. and SPARKE M. (2003) Neoliberal geopolitics. Antipode 35(5) 886-897.

ROSE N. (1993). Government, authority and expertise in advanced liberalism. Economy and Society 22(3) 283-299.

ROSE N. (1999) Powers of Freedom: Reframing Political Thought. Cambridge University Press, Cambridge.

ROSE N. (2001) The politics of life itself. Theory, Culture \& Society 18(1) 1-30.

ROSE N. and MILLER P. (1992) Political power beyond the state: problematics of government. The British Journal of Sociology 43(2) 173-205.

ROSE N., O’MALLEY P. and VALVERDE M. (2006) Governmentality. Annual Review of Law and Social Science 2 83-104. 
SALTMAN R. B. and FIGUERAS J. (1997) European Health Care Reform: An Analysis of Current Strategies. World Health Organization, Regional Office for Europe, Copenhagen.

SALTMAN R. B. and BANKAUSKAITE V. (2006) Conceptualizing decentralization in European health systems: a functional perspective. Health Economics, Policy and Law 1(2) $127-147$.

SOSIAALI- JA TERVEYDENHUOLLON TAVOITE- JA TOIMINTAOHJELMA 20042007 (2004) Sosiaali- ja terveysministeriön julkaisuja 2003: 20. Ministry of Social Affairs and Health, Helsinki.

SOSIAALI- JA TERVEYDENHUOLLON KANSALLINEN KEHITTÄMISOHJELMA 2008-2011 (2008) Sosiaali-ja terveysministeriön julkaisuja 2008: 6. Ministry of Social Affairs and Health, Helsinki.

SOSIAALI- JA TERVEYDENHUOLLON KANSALLINEN KEHITTÄMISOHJELMA 2012-2015 (2012) Sosiaali-ja terveysministeriön julkaisuja 2012: 1. Ministry of Social Affairs and Health, Helsinki.

SVT XI: 63 Suomen virallinen tilasto. Yleinen terveyden- ja sairaanhoito 1960. National Board of Health, Helsinki.

SVT XI: 73 Suomen virallinen tilasto. Yleinen terveyden- ja sairaanhoito1970. National Board of Health, Helsinki. 
SVT XI: 74 Suomen virallinen tilasto. Lääkintöhallituksen vuosikirja 1971-1977. National Board of Health, Helsinki.

SVT XI: 77 Suomen virallinen tilasto. Lääkintöhallituksen vuosikirja 1979-1980. National Board of Health, Helsinki.

TAYLOR P. (1994) The state as a container: territoriality in the modern world-system. Progress in Human Geography 18(3) 151-162.

TEGHTSOONIAN K. (2009) Depression and mental health in neoliberal times: a critical analysis of policy and discourse. Social Science \& Medicine 69(1) 28-35.

TERVEYDENHUOLLON OHJELMA VUOSILLE 1975-1979 (1974). National Board of Health, Helsinki.

TUOHY C. H. (2012) Reform and the politics of hybridization in mature health care states. Journal of Health Politics, Policy and Law 37(4) 611-632.

VALTAKUNNALLINEN SUUNNITELMA KANSANTERVEYSTYÖN

JÄRJESTÄMISESTÄ VUOSINA 1972-1976 (1972). National Board of Health, Helsinki.

VALTAKUNNALLISET SUUNNITELMAT KANSANTERVEYSTYÖN JA SAIRAANHOITOLAITOSTEN TOIMINNAN JÄRJESTÄMISESTÄ VUOSINA 1975-1979 (1974). National Board of Health, Helsinki. 
VALTAKUNNALLISET SUUNNITELMAT KANSANTERVEYSTYÖN JA SAIRAANHOITOLAITOSTEN TOIMINNAN JÄRJESTÄMISESTÄ VUOSINA 1977-1981 (1976). National Board of Health, Helsinki.

\section{VALTAKUNNALLISET SUUNNITELMAT KANSANTERVEYSTYÖN JA}

SAIRAANHOITOLAITOSTEN TOIMINNAN JÄRJESTÄMISESTÄ VUOSINA 1978-1982 (1977). National Board of Health, Helsinki.

VALTAKUNNALLISET SUUNNITELMAT KANSANTERVEYSTYÖN JA SAIRAANHOITOLAITOSTEN TOIMINNAN JÄRJESTÄMISESTÄ VUOSINA 1980-1984 (1979). National Board of Health, Helsinki.

VALTAKUNNALLISET SUUNNITELMAT SOSIAALIHUOLLON JA TERVEYDENHUOLLON JÄRJESTÄMISESTÄ VUOSINA 1984-1988 (1983). National Board of Health, Helsinki.

VALTAKUNNALLINEN SUUNNITELMA SOSIAALI- JA TERVEYDENHUOLLON JÄRJESTÄMISESTÄ VUOSINA 1993-1996 (1992). Ministry of Social Affairs and Health, Helsinki.

VALVERDE M. (2007) Genealogies of European states: Foucauldian reflections. Economy and Society 36(1), 159-178. 
VUORENKOSKI L., MLADOVSKY P. and MOSSIALOS E. (2008) Finland: health system review. Health Systems in Transition 10(4) 1-168.

WALTERS W. (2012) Governmentality: Critical Encounters. Routledge, New York.

WENDT C. and KOHL J. (2010) Translating monetary inputs into health care provision: a comparative analysis of the impact of different modes of public policy. Journal of Comparative Policy Analysis: Research and Practice 12(1-2) 11-31.

WREDE S. (2001) Decentering Care for Mothers. The Politics of Midwifery and the Design of Finnish Maternity Services. Åbo Akademi University Press, Åbo.

WREDE S. (2008) Unpacking gendered professional power in the welfare state. Equal Opportunities International 27(1) 19-33.

YRJÄLÄ A. (2005) Public health and Rockefeller wealth. Alliance strategies in the early formation of Finnish public health nursing. Åbo Akademi University Press, Åbo. 